\title{
PRECLINICAL DETECTION IN JAPANESE FAMILIES WITH MYOTONIC DYSTROPHY USING POLYMORPHIC DNA MARKERS
}

\author{
Yuji Takemoto, ${ }^{1}$ Tetsuro Miki, ${ }^{1}$ Jun Nakura, ${ }^{1}$ Kumi Nishikawa, ${ }^{1}$ \\ Kouzin Kamino, ${ }^{1}$ Shunichi Takeda, ${ }^{2}$ Kogo Kuzu, ${ }^{2}$ Mitsuhiro Osame, ${ }^{3}$ \\ Masanori NaKagaWA, ${ }^{4}$ Itsuro HiguchI, ${ }^{3}$ Takeshi YamadA ${ }^{5}$, \\ Tetsuya Takayanagi, ${ }^{6}$ Shiro Matsubara, ${ }^{7}$ Kyoko Saita, ${ }^{8}$ \\ Shin-ichiro TaKaI, ${ }^{9}$ Tasuku HonJo, ${ }^{2}$ and Toshio OGIHARA ${ }^{1}$ \\ ${ }^{1}$ Department of Geriatric Medicine, Osaka University Medical School, \\ Fukushima-ku, Osaka 553, Japan \\ ${ }^{2}$ Department of Medical Chemistry, Faculty of Medicine, Kyoto University, \\ Sakyo-ku, Kyoto 606, Japan \\ ${ }^{3}$ Third Department of Internal Medicine, Kagoshima University Medical School, \\ Ushuku, Kagoshima 890, Japan \\ ${ }^{4}$ National Sanatorium Okinawa Hospital, \\ Ganeko, Okinawa 901-22, Japan \\ ${ }^{5}$ Department of Neurology, Kyushu University Medical School, \\ Higashi-ku, Fukuoka 812, Japan \\ ${ }^{6}$ Department of Neurology, Nara Medical College, \\ Kashiwara, Nara 634, Japan \\ 'Department of Neurology, Kanazawa University Medical School, \\ Takaramachi, Kanazawa 920, Japan \\ ${ }^{8}$ National Sanatorium Utano Hospital, \\ Ukyo-ku, Kyoto 616, Japan \\ ${ }^{9}$ Second Department of Surgery, Osaka University Medical School, \\ Fukushima-ku, Osaka 553, Japan
}

Summary Myotonic dystrophy (DM) is a genetic disease inherited by an autosomal dominant trait and characterized by multi-organ disorders. Although its biochemical basis has been unknown, the DM locus is closely linked to D19S19 and APOC2 on the long arm of chromosome 19 both in Japanese and Caucasian populations. Linkage studies of Japanese DM families using these polymorphic DNA markers detected two asymptomatic gene carriers in two unrelated families.

Key Words myotonic dystrophy, DNA diagnosis, apolipoprotein CII (APOC2), D19S19, restriction fragment length polymorphisms (RFLPs)

Received July 28, 1989; revised version received September 1, 1989; Accepted September 21, 1989. 


\section{INTRODUCTION}

Myotonic dystrophy (DM), the most common form of adult muscular dystrophy, is inherited in an autosomal dominant fashion. The prevalence of DM has been estimated to be 5 per $10^{5}$ both in Caucasian and Japanese populations (Osame and Furusho, 1983). Neither the gene responsible for DM or its basal disorder has yet been identified. Linkage analysis between the DM locus and APOC2 (apolipoprotein C-II) in Caucasian families has demonstrated that the DM locus is located to the long arm of the chromosome 19 (Shaw et al., 1985). Recently we have reported that in Japanese families the DM locus is also closely linked to D19S19 and APOC2 on chromosome 19 (Takemoto et al., 1989). Therefore there would be no genetic heterogeneity for the DM locus between Caucasian and Japanese populations and the prediction of an affected member of Japanese DM families can be established. Since age of onset and the clinical symptoms and signs are different among not only the DM patients from unrelated DM families but also affected members of the same DM family, it is difficult to detect a presymptomatic patient or an asymptomatic carrier in DM families by conventional clinical examination. Clinical application of the molecular genetics enables us to detect an asymptomatic gene carrier in a DM family and to diagnose a fetus at risk for congenital DM whose parent is affected. We have carried out the preclinical detection of a gene carrier in Japanese DM families by linkage analysis using APOC2 and D19S19 as the genetic markers.

\section{MATERIALS AND METHODS}

Peripheral blood samples of DM families were collected by the contribution of the Nishitani's research groups, granted by the Ministry of Health and Welfare of Japan, for the studies of muscular dystrophy. All patients defined as DM satisfied the criteria for DM proposed by the working group on the molecular defect in myotonic dystrophy (Griggs et al., 1989). DNA was extracted from peripheral white blood cells by using the method of Nishisho et al. (1986) and digested with restriction enzyme according to conditions of the suppliers (Takara, Kyoto). Samples were run on $0.7 \%$ agarose gels and blotted on nylon-membrane filter (HybondN, Amersham).

DNA probes were LDR152 (D19S19) and NJ3.6, cDNA of APOC2, kindly gifted by Roses and Humphries, respectively. LDR152 detects a PstI polymorphism with $19 \mathrm{~kb}$ and $11 \mathrm{~kb}$ alleles (Bartlett et al., 1987). NJ 3.6 detects TaqI polymorphic bands with $3.8 \mathrm{~kb}$ and $3.5 \mathrm{~kb}$ (Myklebost et al., 1984; Shaw et al., 1985). DNA probes were prepared by the oligolabeling method with $\left[{ }^{32} \mathrm{P}\right] \mathrm{dCTP}$. Blots were hybridized with radio-labeled probes in $6 \times \mathrm{SSC}, 5 \times$ Denharts' solution and $100 \mu \mathrm{g}$ salmon sperm $\mathrm{DNA} / \mathrm{ml}$ at $65^{\circ} \mathrm{C}$ for at least $12 \mathrm{hr}$. Filters were washed twice at 
$65^{\circ} \mathrm{C}$ with $2 \times \mathrm{SSC}-0.5 \% \mathrm{SDS}$ for $20 \mathrm{~min}$ and once at $65^{\circ} \mathrm{C}$ with $1 \times \mathrm{SSC}-0.5 \%$ SDS for $20 \mathrm{~min}$. The final wash of the hybridized blots consisted of $0.1 \% \mathrm{SSC}$ $0.1 \% \mathrm{SDS}$ at $65^{\circ} \mathrm{C}$ for $20 \mathrm{~min}$. Washed blots were exposed to X-ray film (Kodak $\mathrm{XS}-1)$ at $-70^{\circ} \mathrm{C}$ for $1-3$ days.

\section{RESULTS}

In 16 families including 81 members, 7 and 6 families were informative for LDR152 and NJ3.6, respectively. Two asymptomatic patients from two different families have been detected.

Family 18. Both allele A of the Pst $\mathrm{T}$ polymorphism of LDR152 (Fig. 1) and allele D of the TaqI polymorphism of LDR152 (Fig. 1) and allele D of the TaqI polymorphism of APOC2 (Fig. 2) cosegregated with the DM gene in this family. II-3, aged 32 years old, is clinically normal. It is more than $95 \%$ certain that she has received the mutant DM gene with alleles $\mathrm{A}$ and $\mathrm{D}$ from her affected father. We expect that she is an asymptomatic carrier, although we can not exclude a rare recombination event between the DM locus and APOC2 as reported by Johnson et al. (1988).

Family 20. II-3, aged 70 years old, revealed no typical DM features except cataract which had been treated by an ophthalmologist. Differential diagnosis of his cataract was difficult because of combined senile cataract. He should be an obligate gene carrier, because he has three affected children and one affected nephew. Although IV-5, aged 15 years old, is clinically normal, he has inherited the allele A cosegregating with the DM gene and might be an asymptomatic gene carrier (Fig. 1).

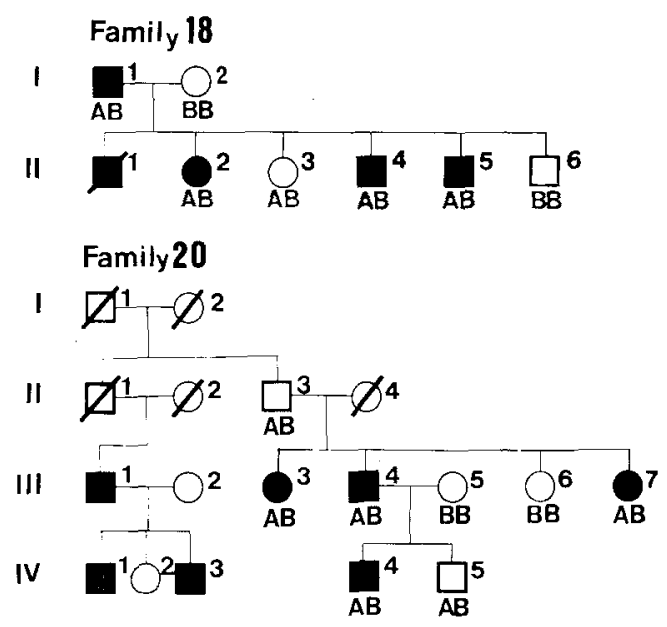

Fig. 1. Hybridization patterns of LDR152 (D19S19) to genomic DNA from members of family 18 and 20 after digestion with Pst. RFLPS are $19 \mathrm{~kb}(\mathrm{~A})$ and $11 \mathrm{~kb}$ (B). II- 3 in family 20 is an obligate gene carrier. 

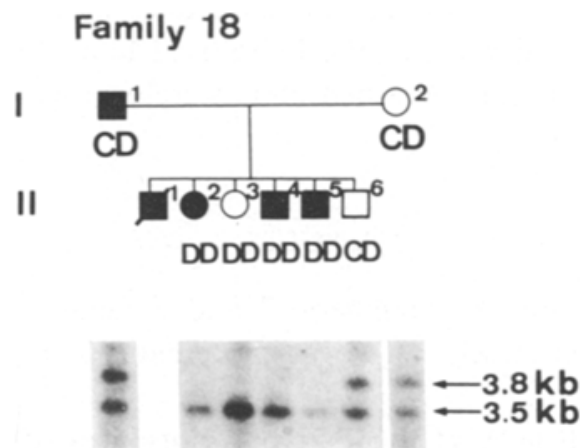

Family 20

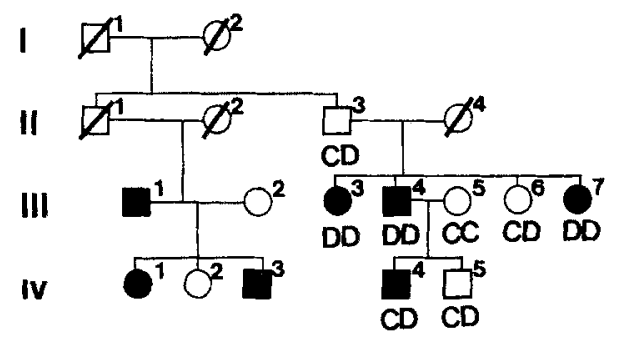

Fig. 2. Hybridization patterns of NJ.3.8 to genomic DNA from members of family 18 and 20 after digestion with TaqI. RFLPs are $3.8 \mathrm{~kb}(\mathrm{C})$ and $3.5 \mathrm{~kb}(\mathrm{D})$.

\section{DISCUSSION}

Polymorphic DNA markers have become important for the prediction of a gene carrier and prenatal diagnosis in genetic diseases where the affected gene has not been identified and isolated. In the case of DM the gene responsible is unknown and to make a diagnosis we need to use polymorphic DNA markers linked to the DM locus. In Caucasian DM families APOC2 and D19S19 are tightly linked to the DM locus and these DNA markers are frequently used to detect a gene carrier in families with DM by linkage analysis. Since the recombination frequency between APOC2 and the DM locus is 0.04 with a maximum lod score of 23.9, a gene carrier can be detected with a $94.7 \%$ accuracy using APOC2 polymorphism (Meredith et al., 1986). Lunt et al. (1986) reported prenatal diagnosis of a first trimester fetus at risk for DM by analysis of DNA from chorionic villi.

Recently we have carried out linkage analysis between the Japanese DM locus and the two DNA markers, D19S19 and APOC2, in order to exclude the genetic heterogeneity of the DM gene among races. Because the genetic heterogeneity of genetic diseases such as polycystic kidney disease (Romeo et al., 1988) and Alzheimer's disease (Schellenberg et al., 1988) has been reported. The maximum lod score of 3.38 at $0 \%$ recombination between the Japanese DM locus and D19S19 
supports that the Japanese DM locus might also be on the long arm of chromosome 19 and that we can predict an affected member in Japanese DM families by linkage analysis (Takemoto et al., 1989).

In family 18 where both APOC2 and D19S19 are informative, we were able to diagnose II-3 as an asymptomatic carrier assuming that the event of crossover between the DM locus and these two markers was negligible. In family 20 , the predicted risk of IV-5 carrying the DM gene could be $94.7 \%$. We thought that II-3 would be an obligate gene carrier. He satisfied the criterion 3 for DM, proposed by the working group (Griggs et al., 1989), which mentioned an obligate heterozygote who has a child with definite DM and a parent, sibling, niece or nephew with definite DM. It has been reported a DM family with an elderly person over 70 years old appearing normal with normal EMG who was subsequently determined to be an obligate gene carrier from pedigree analysis (Streib et al., 1987). Osame and Furusho (1983) demonstrated that 4 out of 64 families showed skipped generation and the penetrance of DM in Japanese families was $94 \%$ by pedigree analysis.

For the purpose of the more accurate detection of a gene carrier and prenatal diagnosis, we need to isolate the closer polymorphic DNA markers to the DM gene or the DM gene itself.

Acknowledgment We thank Dr. A.D. Roses and Dr. S.E. Humphries for the use of D19S19 and APOC2, respectively. We also thank Dr. K. Johnson for helpful suggestions and comments and Mrs. Hirota for technical assistance.

This work was supported by a grant from the Nissan Science Foundation.

\section{REFERENCES}

Bartlett, R.J., Pericak-Vance, M.A., Yamaoka, L., Gilbert, J., Herbstreith, M., Hung, W.-Y., Lee, J.E., Mohandas, T., Bruns, G., Laberge, C., Thibault, M.-C., Ross, D. and Roses, A.D. 1987. A new probe for the diagnosis of myotonic muscular dystrophy. Science 235: 1648-1650.

Griggs, R., Wood, D., Moxley, R., Ashizawa, T., Epstein, H., Hejtmancik, F., Bartllet, R., Gilbert, J., Lee, J., Pericak-Vance, M., Roses, A., Brook, J., Howell, R., Johnson, K., Junien, C., Korneluk, R., Mohrenweiser, H., Ropers, H-H., Shaw, D., Siciliano, M. and Todd, J. 1989. Criteria for establishing the validity of genetic recombination in myotonic dystrophy. Neurology 39: $420-421$.

Johnson, K., Nimmo, E., Jones, P., Weiss, M., Savontaus, M.-L., Anvret, M., Bartlett, R., Roses, A., Shaw, D., Harper, P.S., Koivunen-Tapio, E. and Williamson, R. 1988. Segregation of linked probes to myotonic dystrophy in a family demonstrating that 152 and APOC2 are on the same side of DM on 19q. Hum. Genet. 80:379-381.

Lunt, P.W., Meredith, A.L. and Harper, P.S. 1986. First-trimester prediction in fetus at risk for myotonic dystrophy. Lancet II: $350-351$.

Meredith, A.L., Huson, S.M., Lunt, P.W., Sarfarazi, M., Harley, H.G., Brook, J.D. and Harper, P.S. 1986. Application of a closely linked polymorphism of restriction fragment length to counselling and prenatal testing in families with myotonic dystrophy. Br. Med. J. 293: 13531356.

Myklebost, O., Williamson, R., Markham, A.F., Myklebost, S.R., Rogers, J., Woods, D.E. and Humphries, S.E. 1984. The isolation and characterisation of cDNA clones for human apolipoprotein C-II. J. Biol. Chem. 259 : 4401-4404. 
Nishisho, I., Miki, T., Tateishi, H., Takai, S., Motomura, K., Nakura, J., Kumahara, Y., Mori, T. and Honjo, T. 1986. Isolation of DNA clones revealing restriction fragment length polymorphisms in the human genome. Jpn. J. Human Genet. 31: 249-258.

Osame, M. and Furusho, T. 1983. Genetic epidemiology of myotonic dystrophy in Kagoshima and Okinawa districts in Japan. Clin. Neurol. 23: 1067-1071.

Romeo, G., Devoto, M. and Costa, G. 1988. A second genetic locus for autosomal dominant polycystic kidney disease. Lancet 2: 8-10.

Schellenberg, G.D., Bird, T.D., Wijsman, E.M., Moore, D.K., Boehnke, M., Bryant, E.M., Lampe, T.H., Nochlin, D., Sumi, S.M., Deeb, S.S., Beyreuther, K. and Martin, G.M. 1988. Absence of linkage of chromosome 21q21 markers to familial Alzheimer's disease. Science 241 : 15071510.

Shaw, D.J., Meredith, A.L., Sarfarazi, M., Huson, S.M., Brook, J.D., Myklebost, O. and Harper, P.S. 1985. The apolipoprotein CII gene: Subchromosomal localization and linkage to the myotonic dystrophy locus. Hum. Genet. 70: 271-273.

Streib, E.W., Fine, B., Sun, F. and Aita, J.F. 1987. Myotonic dystrophy sine myotonia: Normal EMG in two obligate gene-carriers of advanced age. Electromyogr. Clin. Neurophysiol. 27: $443-446$.

Takemoto, Y., Miki, T., Nishikawa, K., Nakura, J., Kamino, K., Takai, S., Honjo, T. and Ogihara, T. 1989. The locus of Japanese myotonic dystrophy is also linked to D19S19 on the long arm of chromosome 19. Genomics in press. 